\title{
Influenza pandemics: past and future Peter Palese*
}

Address: Department of Microbiology, Mount Sinai School of Medicine, New York, New York, 10029, USA

* Corresponding author

from 2006 International Meeting of The Institute of Human Virology

Baltimore, USA. 17-2I November, 2006

Published: 2I December 2006

Retrovirology 2006, 3(Suppl I):S55 doi:I0.I I86/I742-4690-3-SI-S55

(C) 2006 Palese; licensee BioMed Central Ltd.

The influenza pandemic of 1918/1919 was a unique event in recorded history, costing on the order of 50 million lives within the time span of only several months. The virus is extinct, but the advent of reverse genetics techniques for negative strand RNA viruses (a family of viruses which includes the influenza viruses) makes it possible to reconstruct infectious influenza viruses. Based on the nucleotide sequence that was obtained from RNA fragments present in lung samples of victims of the 1918 influenza virus, we succeeded in rebuilding the extinct pandemic virus entirely from commercially available oligonucleotides. This virus turned out to be highly virulent in the mouse model, more than any other human influenza virus strain tested. It also was shown to be highly pathogenic for chicken embryos and grew in human tissue culture cells to high titers and replicated in cells in the absence of trypsin (also indicative of high virulence). On the other hand, the 1918 virus was shown to be sensitive to the FDA-approved antivirals (amantadine as well as the neuraminidase inhibitors). We were also able to show that vaccines worked perfectly well in protecting mice against a challenge with a virus containing the 1918 hemagglutinin and neuraminidase genes. We also postulate that the human population, having experienced infections with currently circulating $\mathrm{H} 1 \mathrm{~N} 1$ viruses, is partially immune to a 1918 or 1918-like virus. Finally, we have recently developed a guinea pig transmission model for influenza which will help us to better understand the molecular basis of virulence and the mechanisms by which pandemic influenza viruses are transmitted. [1-3].

\section{References}

I. Palese P, Tumpey TM, Garcia-Sastre A: What can we learn from reconstructing the extinct 1918 pandemic influenza virus? Immunity 2006, 24:121-124.

2. Lowen AC, Mubareka S, Tumpey TM, Garcia-Sastre A, Palese P: The guinea pig as a transmission model for human influenza viruses. Proc Natl Acad Sci USA 2006, 103:9988-9992.

3. Tumpey TM, Basler CF, Aguilar PV, Zeng H, Solorzano A, Swayne DE, Cox NJ, Katz JM, Taubenberger JK, Palese P, Garcia-Sastre A: Characterization of the reconstructed 1918 Spanish influenza pandemic virus. Science 2005, 310:77-80. 